\title{
Energetic Preference of Dative Fluorine-Manganese Bonds Over Direct Manganese-Manganese Bonds in Binuclear Hexafluorocyclopentadiene Manganese Carbonyls
}

\author{
Juanjuan Tan, ${ }^{\mathrm{a}}$ Shida Gong, ${ }^{\mathrm{a}, \mathrm{b}}$ Jianming Deng, ${ }^{\mathrm{a}}$ Qianshu Li, ${ }^{\mathrm{a}}$ Qiong Luo, ${ }^{\mathrm{a}}$ \\ Yaoming Xie, ${ }^{c}$ and R. Bruce King*a,c
}

${ }^{a}$ Key Laboratory of Theoretical Chemistry of Environment, Ministry of Education; Center for Computational Quantum Chemistry; School of Chemistry \& Environment, South China Normal University, Guangzhou 510631, China

${ }^{\mathrm{b}}$ Collaborative Innovation Center for Marine Biomass Fiber Materials and Textiles, College of Chemical Science and Engineering, Shandong Sino-Japanese Center for Collaborative Research of Carbon Nanomaterials, Laboratory of Fiber Materials and Modern Textiles, the Growing Base for State Key Laboratory, Qingdao University, Qingdao 266071, China

${ }^{c}$ Department of Chemistry and Center for Computational Chemistry, University of Georgia, Athens, Georgia 30602, USA

\begin{abstract}
.
Hexafluorocyclopentadiene is known to form binuclear complexes with metal carbonyls, for example $\left(\eta^{2}, \eta^{2}-\mathrm{C}_{5} \mathrm{~F}_{6}\right) \mathrm{Fe}_{2}(\mathrm{CO})_{8}$ and trans- $\left(\eta^{3}, \eta^{1}-\mathrm{C}_{5} \mathrm{~F}_{6}\right) \mathrm{Co}_{2}(\mathrm{CO})_{7}$. In order to evaluate the prospects for related manganese carbonyl chemistry, the $\mathrm{C}_{5} \mathrm{~F}_{6} \mathrm{Mn}_{2}(\mathrm{CO})_{n}(n=10,9,8,7)$ systems were investigated using density functional theory. For the $\mathrm{C}_{5} \mathrm{~F}_{6} \mathrm{Mn}_{2}(\mathrm{CO})_{10}$ system, structures with the $\mathrm{Mn}(\mathrm{CO})_{5}$ units bonded to non-adjacent ring carbon atoms and/or on opposite sides of the $\mathrm{C}_{5} \mathrm{~F}_{6}$ ring are energetically preferred over isomeric structures with the $\mathrm{Mn}(\mathrm{CO})_{5}$ units bonded to adjacent ring carbon atoms and/or on the same side of the $\mathrm{C}_{5} \mathrm{~F}_{6}$ ring. For the unsaturated $\mathrm{C}_{5} \mathrm{~F}_{6} \mathrm{Mn}_{2}(\mathrm{CO})_{n}(n=9,8,7)$ systems, structures containing dative $\mathrm{F} \rightarrow \mathrm{Mn}$ bonds from one or both $\mathrm{CF}_{2}$ fluorine atoms to one or both manganese atoms are energetically preferred over structures containing formal $\mathrm{Mn}-\mathrm{Mn}$ bonds. In this way the manganese systems differ significantly from the previously studied iron and cobalt systems.
\end{abstract}

Keywords. Density functional theory (DFT), transition metal carbonyls, fluorinated ligands R. Bruce King: e-mail: rbking@ chem.uga.edu; telephone: 1-706-542-1901

Qiong Luo: e-mail: luoqiong@ scnu.edu.cn; telephone: 86-39310439 


\section{Introduction}

The coordination chemistry of transition metals in low formal oxidation states depends on the introduction of strong back-bonding ligands. The classic strong back-bonding ligand is carbon monoxide, which leads to the extensive chemistry of metal carbonyls. ${ }^{1}$ Thus stable zerovalent metal carbonyls include $\mathrm{Cr}(\mathrm{CO})_{6}, \mathrm{Mn}_{2}(\mathrm{CO})_{10}, \mathrm{Fe}(\mathrm{CO})_{5}, \mathrm{Co}_{2}(\mathrm{CO})_{8}, \mathrm{Ni}(\mathrm{CO})_{4}$, all of which are commercially available and have frequent applications in inorganic and organic synthesis, catalysis, and metal deposition. The replacement of hydrogen or alkyl groups with fluorine can also lead to strong back-bonding ligands. The most important ligand of this type is trifluorophosphine, ${ }^{2} \mathrm{PF}_{3}$, which, like $\mathrm{CO}$, forms zerovalent metal complexes such as $\mathrm{Cr}\left(\mathrm{PF}_{3}\right)_{6}$, $\mathrm{Fe}\left(\mathrm{PF}_{3}\right)_{5}$, and $\mathrm{Ni}\left(\mathrm{PF}_{3}\right)_{4}$ that are even more stable than the corresponding zerovalent metal carbonyls.

Perfluoroolefins represent another type of potentially strong back-bonding ligands. The chemistry of perfluoroolefin complexes of metal carbonyls originated in 1959 when Watterson and Wilkinson ${ }^{3}$ investigated the reaction of $\mathrm{Fe}_{3}(\mathrm{CO})_{12}$ with tetrafluoroethylene. The air-stable white crystalline product was originally formulated as $\left(\mathrm{C}_{2} \mathrm{~F}_{4}\right)_{2} \mathrm{Fe}(\mathrm{CO})_{3}$ and believed to be derived from $\mathrm{Fe}(\mathrm{CO})_{5}$ by substitution of two $\mathrm{CO}$ groups with tetrafluoroethylene ligands. However, further study of this complex indicated that two tetrafluoroethylene ligands had coupled to form a ferracyclopentane derivative $\left(\mathrm{CF}_{2}\right)_{4} \mathrm{Fe}(\mathrm{CO})_{4}$ containing a five-membered $\mathrm{C}_{4} \mathrm{Fe}$ ring (Figure 1). ${ }^{4,5}$ Nevertheless, Haszeldine and coworkers ${ }^{6,7}$ found the reaction of tetrafluoroethylene with $\mathrm{Co}_{2}(\mathrm{CO})_{8}$ under mild conditions to give initially a yellow solid formulated as $(\mathrm{OC})_{4} \mathrm{CoCF}_{2} \mathrm{CF}_{2} \mathrm{Co}(\mathrm{CO})_{4}$ with an intact monomeric tetrafluoroethylene ligand bridging two $\mathrm{Co}(\mathrm{CO})_{4}$ unit by forming $\sigma$-bonds to their cobalt atoms (Figure 1). However, this solid reversibly loses $\mathrm{CO}$ under mild conditions to give a red product shown to be $\left(\mu-\mathrm{CF}_{3} \mathrm{CF}\right) \mathrm{Co}_{2}(\mathrm{CO})_{6}(\mu-\mathrm{CO})$ in which a $\mathrm{Co}-\mathrm{Co}$ bond is bridged both by a trifluoromethylfluorocarbene ligand and a CO group (Figure 1). Since these pioneering studies the chemistry of fluoroolefin metal carbonyl complexes has developed extensively as suitable fluoroolefin ligands became available. ${ }^{8,9}$

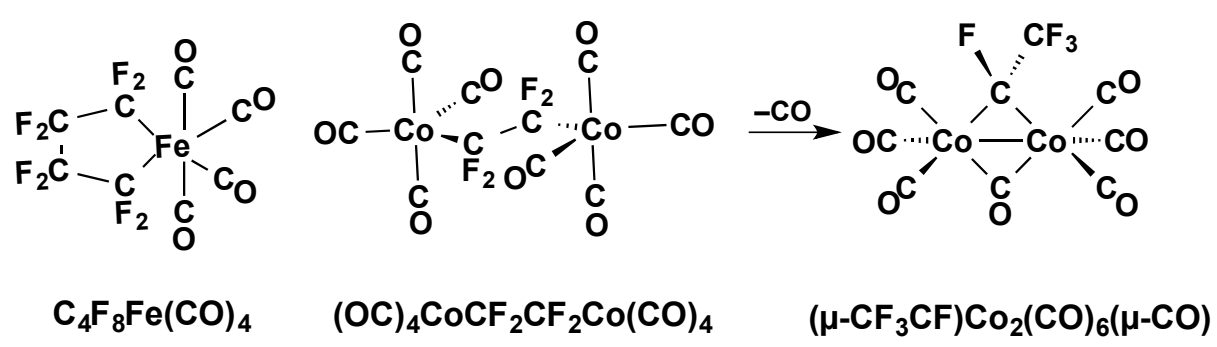

Figure 1. Iron and cobalt carbonyl complexes obtained from tetrafluoroethylene. 
In view of this metal carbonyl chemistry of tetrafluoroethylene, the perfluorinated diolefin hexafluorocyclopentadiene, $\mathrm{C}_{5} \mathrm{~F}_{6}$, is of interest. The five-membered ring of perfluorocyclopentadiene forces cis geometry simplifying stereochemical issues in its metal complexes. Also note that hexafluorocyclopentadiene differs from its hydrogen analogue, $\mathrm{C}_{5} \mathrm{H}_{6}$, since its reactions with metal carbonyls do not result in fluorine loss to give pentafluorocyclopentadienyl $\left(\mathrm{C}_{5} \mathrm{~F}_{5}\right)$ metal complexes but instead give metal complexes with intact $\mathrm{C}_{5} \mathrm{~F}_{6}$ ligands. In fact, efforts by Seppelt and coworkers to synthesize $\mathrm{C}_{5} \mathrm{~F}_{5}$ metal complexes from hexafluorocyclopentadiene were unsuccessful. ${ }^{10}$ Thus the $\mathrm{C}_{5} \mathrm{~F}_{6}$ complexes $\left(\eta^{2}, \eta^{2}-\mathrm{C}_{5} \mathrm{~F}_{6}\right) \mathrm{Fe}_{2}(\mathrm{CO})_{8}$ and trans $-\left(\eta^{3}, \eta^{1}-\mathrm{C}_{5} \mathrm{~F}_{6}\right) \mathrm{Co}_{2}(\mathrm{CO})_{7}$ are obtained from reactions of hexafluorocyclopentadiene with $\mathrm{Fe}_{2}(\mathrm{CO})_{9}$ and $\mathrm{Co}_{2}(\mathrm{CO})_{8}$, respectively (Figure 2). ${ }^{11,12}$ For comparison, the corresponding reaction of $\mathrm{Fe}_{2}(\mathrm{CO})_{9}$ with cyclopentadiene $\left(\mathrm{C}_{5} \mathrm{H}_{6}\right)$ under mild conditions gives initially the tetrahapto diene complex ${ }^{13}\left(\eta^{4}-\mathrm{C}_{5} \mathrm{H}_{6}\right) \mathrm{Fe}(\mathrm{CO})_{3}$. However, under more vigorous reaction conditions the $\eta^{4}-\mathrm{C}_{5} \mathrm{H}_{6}$ ligand loses hydrogen to give a $\eta^{5}-\mathrm{C}_{5} \mathrm{H}_{5}$ ligand leading ultimately to $\left(\eta^{5}-\mathrm{C}_{5} \mathrm{H}_{5}\right)_{2} \mathrm{Fe}_{2}(\mathrm{CO})_{2}(\mu-\mathrm{CO})_{2}$ as the apparent thermodynamic sink in such systems. ${ }^{14,15,16,17}$ The corresponding reaction of $\mathrm{Co}_{2}(\mathrm{CO})_{8}$ with cyclopentadiene appears to give directly $\left(\eta^{5}-\mathrm{C}_{5} \mathrm{H}_{5}\right) \mathrm{Co}(\mathrm{CO})_{2}$ without any evidence for isolable $\mathrm{C}_{5} \mathrm{H}_{6}$-cobalt complexes such as binuclear $\left(\eta^{4}-\mathrm{C}_{5} \mathrm{H}_{6}\right)_{2} \mathrm{Co}_{2}(\mathrm{CO})_{4}$ complexes formed by diolefins such as butadiene and 1,3-cyclohexadiene.

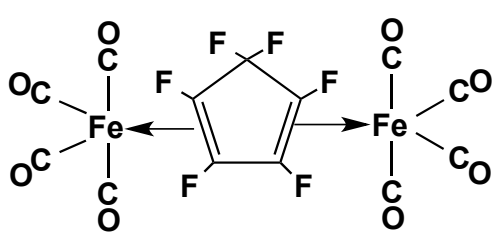

$\left({ }^{2},{ }^{2}-\mathrm{C}_{5} \mathrm{~F}_{6}\right) \mathrm{Fe}_{2}(\mathrm{CO})_{8}$

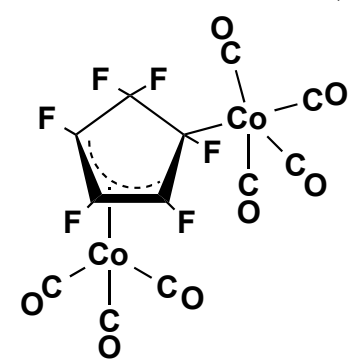

$\left({ }^{3},{ }^{1}-\mathrm{C}_{5} \mathrm{~F}_{6}\right) \mathrm{Co}_{2}(\mathrm{CO})_{7}$

Figure 2. Structures of the binuclear iron and cobalt carbonyl complexes of hexafluorocyclopentadiene.

The two known hexafluorocyclopentadiene metal carbonyls (Figure 2) are binuclear complexes without a metal-metal bond. However, the bonding modes of the $\mathrm{C}_{5} \mathrm{~F}_{6}$ ligand differ in these two complexes. In the iron complex $\left(\eta^{2}, \eta^{2}-C_{5} F_{6}\right) F_{2}(C O)_{8}$ the $C_{5} F_{6}$ ligand is a bisdihapto $\eta^{2}, \eta^{2}-\mathrm{C}_{5} \mathrm{~F}_{6}$ ligand with each $\mathrm{C}=\mathrm{C}$ double bond connected to an $\mathrm{Fe}(\mathrm{CO})_{4}$ unit through a dative bond. However, in the cobalt complex $\left(\eta^{3}, \eta^{1}-\mathrm{C}_{5} \mathrm{~F}_{6}\right) \mathrm{Co}_{2}(\mathrm{CO})_{7}$ the $\mathrm{C}_{5} \mathrm{~F}_{6}$ ligand is a trihapto-monohapto ligand with three of its four $\mathrm{sp}^{2}$ carbons bonded to a $\mathrm{Co}(\mathrm{CO})_{3}$ moiety and the fourth $\mathrm{sp}^{2}$ carbon bonded to a $\mathrm{Co}(\mathrm{CO})_{4}$ moiety. These bonding modes of the $\mathrm{C}_{5} \mathrm{~F}_{6}$ ligand in $\left(\eta^{2}, \eta^{2}-\mathrm{C}_{5} \mathrm{~F}_{6}\right) \mathrm{Fe}_{2}(\mathrm{CO})_{8}$ and $\left(\eta^{3}, \eta^{1}-\mathrm{C}_{5} \mathrm{~F}_{6}\right) \mathrm{Co}_{2}(\mathrm{CO})_{7}$ give each transition metal atom in these structures the favored 18-electron configuration. 
Application of the 18-electron rule suggests that decarbonylation of $\left(\eta^{2}, \eta^{2}-\mathrm{C}_{5} \mathrm{~F}_{6}\right) \mathrm{Fe}_{2}(\mathrm{CO})_{8}$ and $\left(\eta^{3}, \eta^{1}-\mathrm{C}_{5} \mathrm{~F}_{6}\right) \mathrm{Co}_{2}(\mathrm{CO})_{7}$ should give structures with formal metal-metal bonds. Previous papers have explored such possibilities for both the iron ${ }^{18}$ and cobalt ${ }^{19}$ systems using density functional theory. In order to gain further insight regarding possible bonding modes of the hexafluorocyclopentadiene ligand in binuclear metal complexes, we have now used similar density functional methods to study the corresponding manganese carbonyl complexes $\left(\mathrm{C}_{5} \mathrm{~F}_{6}\right) \mathrm{Mn}_{2}(\mathrm{CO})_{n}(n=10,9,8,7)$. This research has led to the discovery of a new structural feature in low-energy $\left(\mathrm{C}_{5} \mathrm{~F}_{6}\right) \mathrm{Mn}_{2}(\mathrm{CO})_{n}(n=8,7)$ structures, namely the coordination of a $\mathrm{CF}_{2}$ fluorine atom as well as the $\mathrm{C}=\mathrm{C}$ double bonds of the hexafluorocyclopentadiene ligand to the central $\mathrm{Mn}_{2}$ unit, as indicated by bonding $\mathrm{Mn}-\mathrm{F}$ distances. This structural feature was not found in the previous experimental and theoretical studies of hexafluorocyclopentadiene complexes of iron $^{11,18}$ and cobalt ${ }^{12,19}$ carbonyls. However, related structural features have been predicted by density functional theory to occur in some iron carbonyl complexes containing $\mathrm{PF}_{3}{ }^{20}$ and $\mathrm{CF}_{2}{ }^{21}$ ligands.

\section{Theoretical Methods}

Electron correlation effects were considered by using density functional theory (DFT) methods, which have evolved as a practical and effective computational tool, especially for organometallic compounds. ${ }^{22,23,24,25,26,27,28,29}$ Two DFT methods (B3LYP and BP86) were used in this study. The B3LYP method is the hybrid HF/DFT method using a combination of the three-parameter Becke functional ${ }^{30}$ with the Lee-Yang-Parr (LYP) generalized gradient correlation functional. ${ }^{31}$ The BP86 method combines Becke's 1988 exchange functional ${ }^{32}$ with Perdew's 1986 gradient corrected correlation functional. ${ }^{33}$

All computations were performed using double- $\zeta$ plus polarization (DZP) basis sets. For carbon, oxygen, and fluorine these DZP basis sets are obtained by adding one set of pure spherical harmonic $d$ functions with orbital exponents $\alpha_{d}(C)=0.75, \alpha_{d}(O)=0.85$, and $\alpha_{d}(F)=$ 1.00 to the standard Huzinaga-Dunning contracted DZ sets. ${ }^{34,35}$ The loosely contracted DZP basis set for manganese is the Wachters primitive set $^{36}$ augmented by two sets of $\mathrm{p}$ functions and one set of $\mathrm{d}$ functions, contracted following Hood, Pitzer, and Schaefer, ${ }^{37}$ and designated as (14s11p6d/10s8p3d).

The geometries of all structures were fully optimized using the DZP B3LYP and DZP BP86 methods. All computations were carried out with the Gaussian 03 program. ${ }^{38}$ The dispersion effect on the geometries and relative energies of the structures were explored by using the DZP B3LYP-D3(BJ) and DZP BP86-D3(BJ) methods with the Gaussian 09 program, ${ }^{39}$ The results are listed in the Supporting Information (Tables S38-S39). Since the differences resulting 
from this effect are small, the dispersion effect was not taken into further consideration in this study.

In the search for minima using all currently implemented DFT methods, low magnitude imaginary vibrational frequencies are suspect because of significant limitations in the numerical integration procedures used in the DFT computations. ${ }^{40}$ Thus all imaginary vibrational frequencies with a magnitude less than $50 i \mathrm{~cm}^{-1}$ are considered questionable, and are given less weight in the analysis. ${ }^{41,42}$ Therefore we do not always follow such low imaginary vibrational frequencies.

The structures of $\left(\mathrm{C}_{5} \mathrm{~F}_{6}\right) \mathrm{Mn}_{2}(\mathrm{CO})_{\mathrm{n}}$ are designated as $\mathbf{n - a S}$ (or $\mathbf{n - a T}$ ), where $\mathbf{n}$ is the number of $\mathrm{CO}$ groups, and $\mathbf{a}$ orders the structures according to their relative energies. $\mathbf{S}$ and $\mathbf{T}$ represent singlet and triplet, respectively. Thus the lowest-lying singlet $\left(\mathrm{C}_{5} \mathrm{~F}_{6}\right) \mathrm{Mn}_{2}(\mathrm{CO})_{10}$ structure is designated as 10-1S.

\section{Results and Discussion}

\section{1. $\left(\mathrm{C}_{5} \mathrm{~F}_{6}\right) \mathrm{Mn}_{2}(\mathrm{CO})_{10}$}

Four low-energy $\left(\mathrm{C}_{5} \mathrm{~F}_{6}\right) \mathrm{Mn}_{2}(\mathrm{CO})_{10}$ structures are found to have the $(\mathrm{OC})_{5} \mathrm{Mn}-\left(\mathrm{C}_{5} \mathrm{~F}_{6}\right)-$ $\mathrm{Mn}(\mathrm{CO})_{5}$ geometry without a metal-metal bond (Figure 3 and Table 1). The Mn-C(ring) bond distances in these structures are predicted to range from 2.17 to $2.24 \AA$. The uncomplexed $\mathrm{C}=\mathrm{C}$ double bond length is $\sim 1.34 \AA$. These four $(\mathrm{OC})_{5} \mathrm{Mn}-\left(\mathrm{C}_{5} \mathrm{~F}_{6}\right)-\mathrm{Mn}(\mathrm{CO})_{5}$ structures differ only in the positions of the two $\mathrm{Mn}(\mathrm{CO})_{5}$ fragments.

The global minimum 10-1S of $\left(\mathrm{C}_{5} \mathrm{~F}_{6}\right) \mathrm{Mn}_{2}(\mathrm{CO})_{10}$ has trans stereochemistry, i.e., the two $\mathrm{Mn}(\mathrm{CO})_{5}$ moieties are connected to the 2- and 5- carbon atoms and are located on opposite sides of the $\mathrm{C}_{5} \mathrm{~F}_{6}$ ring (Figure 3 and Table 1). The $C_{s}$ structure 10-2S is the cis stereoisomer of 10-1S, lying only $1.5 \mathrm{kcal} / \mathrm{mol}$ (B3LYP) or $1.1 \mathrm{kcal} / \mathrm{mol}$ (BP86) in energy above 10-1S. The long $\mathrm{Mn}^{\cdots} \mathrm{F}$ distances of $\sim 2.92 \AA$ in both 10-1S and 10-2S indicate the absence of direct Mn-F bonds. The manganese atoms in both 10-1S and 10-2S have the favored 18-electron configuration.

Structures 10-3S and 10-4S are another pair of trans/cis stereoisomers of $\left(\mathrm{C}_{5} \mathrm{~F}_{6}\right) \mathrm{Mn}_{2}(\mathrm{CO})_{10}$ (Figure 3 and Table 1). In 10-3S and $\mathbf{1 0 - 4 S}$ the two $\mathrm{Mn}(\mathrm{CO})_{5}$ fragments are connected to adjacent carbon atoms in the $\mathrm{C}_{5} \mathrm{~F}_{6}$ ring, leaving an uncomplexed $\mathrm{C}=\mathrm{C}$ double bond adjacent to the $\mathrm{CF}_{2}$ group. The trans structure $\mathbf{1 0 - 3 S}$ lies only $4.7 \mathrm{kcal} / \mathrm{mol}$ (B3LYP) or $4.3 \mathrm{kcal} / \mathrm{mol}$ (BP86) in energy above 10-1S. However, the cis structure 10-4S is a much higher energy structure, lying $18.1 \mathrm{kcal} / \mathrm{mol}$ (B3LYP) or $16.7 \mathrm{kcal} / \mathrm{mol}$ (BP86) above 10-1S (Table 1). The high relative energy of the $\operatorname{cis}-\left(\mathrm{C}_{5} \mathrm{~F}_{6}\right) \mathrm{Mn}_{2}(\mathrm{CO})_{10}$ structure 10-4S appears to be a consequence of the steric hindrance of two $\mathrm{Mn}(\mathrm{CO})_{5}$ groups on adjacent carbons on the same side of the $\mathrm{C}_{5} \mathrm{~F}_{6}$ ring. The long $\mathrm{Mn}^{\cdots} \mathrm{F}$ distances in $\mathbf{1 0 - 3 S}$ of $\sim 2.93 \AA$ and in 10-4S of $\sim 2.90 \AA$ indicate the 
absence of direct Mn-F bonds. The manganese atoms in both 10-3S and 10-4S have the favored 18-electron configuration.

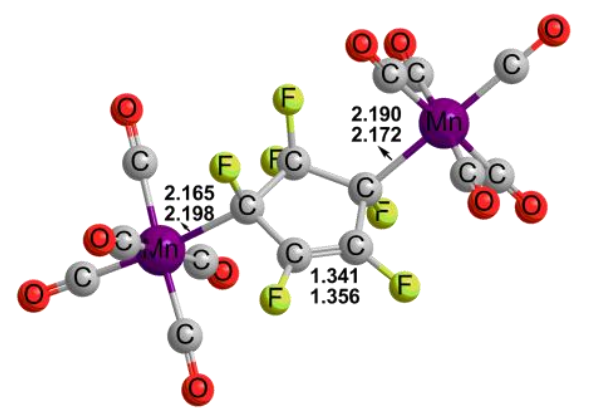

10-1S

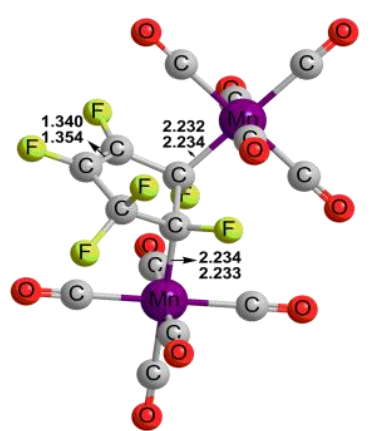

10-3S

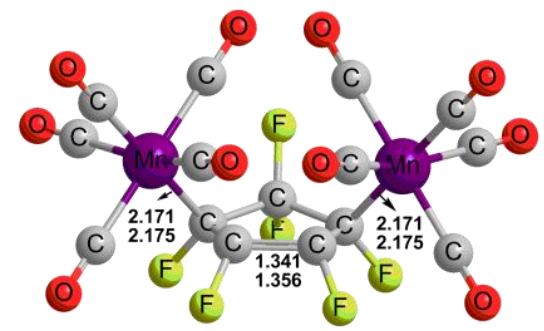

10-2S

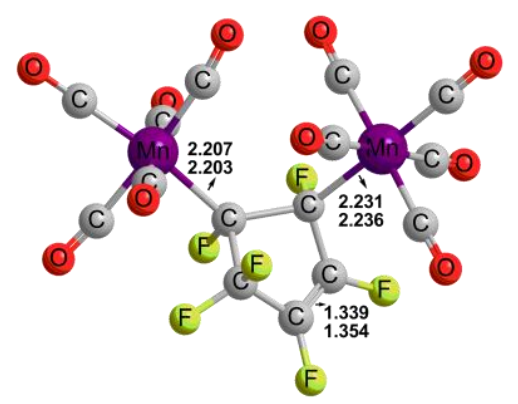

10-4S

Figure 3. Low-energy $\left(\mathrm{C}_{5} \mathrm{~F}_{6}\right) \mathrm{Mn}_{2}(\mathrm{CO})_{10}$ structures. The bond distances are given in $\AA$ with the B3LYP values above and the BP86 values below.

Table 1. Total energies ( $-E$ in a.u.) and relative energies $(\Delta E$ in $\mathrm{kcal} / \mathrm{mol})$ for the optimized $\left(\mathrm{C}_{5} \mathrm{~F}_{6}\right) \mathrm{Mn}_{2}(\mathrm{CO})_{10}$ structures. None of these structures has an imaginary vibrational frequency.

\begin{tabular}{ccc|cc}
\multicolumn{3}{c}{ B3LYP } & \multicolumn{2}{c}{ BP86 } \\
\hline Structures & $-E$ & $\Delta E$ & $-E$ & $\Delta E$ \\
\hline $\mathbf{1 0 - 1 S}$ & 4225.42133 & 0.0 & 4225.89072 & 0.0 \\
$\mathbf{1 0 - 2 S}$ & 4225.41901 & 1.5 & 4225.88896 & 1.1 \\
$\mathbf{1 0 - 3 S}$ & 4225.41391 & 4.7 & 4225.88391 & 4.3 \\
$\mathbf{1 0 - 4 S}$ & 4225.39244 & 18.1 & 4225.86408 & 16.7 \\
\hline
\end{tabular}

\section{2. $\left(\mathrm{C}_{5} \mathrm{~F}_{6}\right) \mathrm{Mn}_{2}(\mathrm{CO})_{9}$}

Three low-energy structures (Figure 4 and Table 2) are found for $\left(\mathrm{C}_{5} \mathrm{~F}_{6}\right) \mathrm{Mn}_{2}(\mathrm{CO})_{9}$. Structure 9-1S is a trans-structure without an $\mathrm{Mn}-\mathrm{Mn}$ bond. The $\eta^{1}, \eta^{3}-\mathrm{C}_{5} \mathrm{~F}_{6}$ ligand bonds as a trihapto ligand to the $\mathrm{Mn}(\mathrm{CO})_{4}$ fragment and as a monohapto ligand to the $\mathrm{Mn}(\mathrm{CO})_{5}$ fragment, as indicated by the $\mathrm{Mn}-\mathrm{C}$ (ring) bonding distances of 2.10 to $2.23 \AA$. The long $\mathrm{Mn} \cdots \mathrm{F}$ distance of 
$3.0 \AA$ in 9-1S indicates the absence of a direct $\mathrm{Mn}-\mathrm{F}$ bond. This gives each manganese atom the favored 18-electron configuration, even in the absence of an Mn-Mn bond.

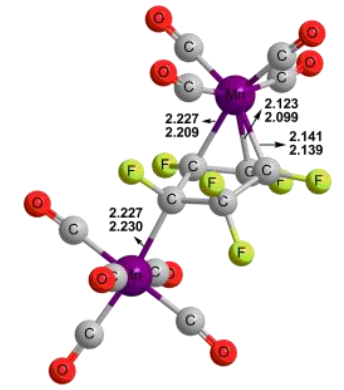

9-1S

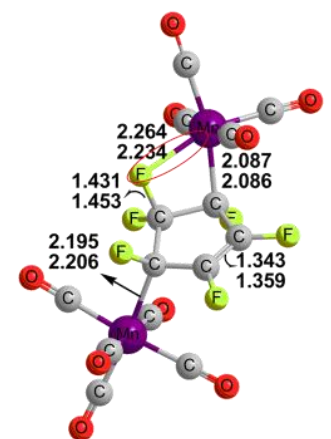

9-2S

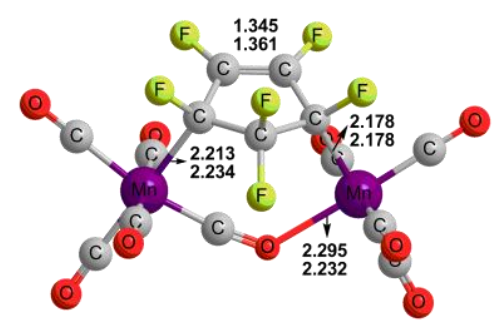

9-3S

Figure 4. Low energy $\left(\mathrm{C}_{5} \mathrm{~F}_{6}\right) \mathrm{Mn}_{2}(\mathrm{CO})_{9}$ structures. The bond distances are given in $\AA$ with the B3LYP values above and the BP86 values below. The F $\rightarrow$ Mn bond in 9-2S is indicated by an oval.

Table 2. Total energies ( $-E$ in a.u.) and relative energies ( $\Delta E$ in $\mathrm{kcal} / \mathrm{mol}$ ) for the optimized $\left(\mathrm{C}_{5} \mathrm{~F}_{6}\right) \mathrm{Mn}_{2}(\mathrm{CO})_{9}$ structures. None of these structures has any imaginary vibrational frequencies.

\begin{tabular}{ccc|cc}
\hline \multicolumn{3}{c|}{ B3LYP } & \multicolumn{2}{c}{ BP86 } \\
\hline structures & $-E$ & $\Delta E$ & $-E$ & $\Delta E$ \\
\hline $\mathbf{9 - 1 S}$ & 4112.04427 & 0.0 & 4112.52083 & 0.0 \\
$\mathbf{9 - 2 S}$ & 4112.04707 & -1.8 & 4112.50995 & 6.8 \\
$\mathbf{9 - 3 S}$ & 4112.03686 & 4.6 & 4112.50022 & 12.9 \\
\hline
\end{tabular}

The $\left(\mathrm{C}_{5} \mathrm{~F}_{6}\right) \mathrm{Mn}_{2}(\mathrm{CO})_{9}$ structure 9-2S lies either $1.8 \mathrm{kcal} / \mathrm{mol}$ (B3LYP) below 9-1S or $6.8 \mathrm{kcal} / \mathrm{mol}$ (BP86) above 9-1S, suggesting these two structures to be nearly degenerate in energy (Figure 4 and Table 2). Structure 9-2S has a trans configuration, in which the $\mathrm{C}_{5} \mathrm{~F}_{6}$ ligand is a monohapto ligand to both the $\mathrm{Mn}(\mathrm{CO})_{5}$ and $\mathrm{Mn}(\mathrm{CO})_{4}$ fragments, as indicated by the $\mathrm{Mn}-\mathrm{C}$ (ring) distances from 2.09 to $2.20 \AA$. This leaves 9-2S with an uncomplexed $\mathrm{C}=\mathrm{C}$ double bond of length $\sim 1.35 \AA$. Unlike 9-1S, one of the two fluorine atoms of the $\mathrm{CF}_{2}$ group in the $\mathrm{C}_{5} \mathrm{~F}_{6}$ ring in 9-2S is close to the $\mathrm{Mn}(\mathrm{CO})_{4}$ fragment with an $\mathrm{F} \rightarrow \mathrm{Mn}$ bonding distance of $\sim 2.25 \AA$ corresponding to donation of a lone pair from this fluorine atom to the manganese atom. This $\mathrm{F} \rightarrow \mathrm{Mn}$ donation slightly activates the corresponding $\mathrm{C}-\mathrm{F}$ bond by lengthening it by 0.06 to 0.08 $\AA$ Á (Table S37 in the Supporting Information). This $\mathrm{F} \rightarrow \mathrm{Mn}$ dative bond allows each manganese atom in 9-2S to have the favored 18-electron configuration. The $\left(\mathrm{C}_{5} \mathrm{~F}_{6}\right) \mathrm{Mn}_{2}(\mathrm{CO})_{9}$ structure 9-2S can be derived from the $\left(\mathrm{C}_{5} \mathrm{~F}_{6}\right) \mathrm{Mn}_{2}(\mathrm{CO})_{10}$ structure 10-1S by replacing a carbonyl group with an $\mathrm{F} \rightarrow \mathrm{Mn}$ dative bond from the $\mathrm{CF}_{2}$ group of the $\mathrm{C}_{5} \mathrm{~F}_{6}$ ligand. Thus each manganese atom in 9-2S has the favored 18-electron configuration. 
The cis $\left(\mathrm{C}_{5} \mathrm{~F}_{6}\right) \mathrm{Mn}_{2}(\mathrm{CO})_{9}$ structure 9-3S, lying $4.6 \mathrm{kcal} / \mathrm{mol}(\mathrm{B} 3 \mathrm{LYP})$ or $12.9 \mathrm{kcal} / \mathrm{mol}$ (BP86) in energy above 9-1S, has a four-electron donor CO group bonded to one manganese atom through its carbon atom and to the other manganese atom through its oxygen atom (Figure 4 and Table 2). Such four-electron donor $\mathrm{CO}$ groups typically bridge metal-metal bonds in polynuclear metal carbonyls. Experimentally known examples of such carbonyl groups in manganese carbonyl chemistry include stable $\left(\mathrm{Ph}_{2} \mathrm{PCH}_{2} \mathrm{PPh}_{2}\right)_{2} \mathrm{Mn}_{2}(\mathrm{CO})_{4}\left(\eta^{2}-\mu-\mathrm{CO}\right)$, structurally characterized by X-ray crystallography, ${ }^{43}, 44$ and $\mathrm{Mn}_{2}(\mathrm{CO})_{8}\left(\eta^{2}-\mu-\mathrm{CO}\right)$, spectroscopically characterized as a transient intermediate or in low-temperature matrices. ${ }^{45}$ However, some chromium carbonyl structures and their thiocarbonyl analogues have been predicted theoretically to contain four-electron donor $\mathrm{CO}$ groups with a linear or bent $\mathrm{Cr}-\mathrm{C}-\mathrm{O} \rightarrow \mathrm{Cr}$ arrangement to attain favorable octahedral chromium coordination and satisfy the 18 -electron rule. ${ }^{46,47}$ A similar situation to these latter chromium carbonyl complexes occurs in 9-3S. The $\mathrm{C}_{5} \mathrm{~F}_{6}$ ring is bonded to the manganese atoms as a bis(monohapto) ligand, as indicated by $\mathrm{Mn}-\mathrm{C}$ (ring) distances of $\sim 2.20 \AA$ and an uncomplexed $\mathrm{C}=\mathrm{C}$ double bond in the $\mathrm{C}_{5} \mathrm{~F}_{6}$ ring of length $\sim 1.35 \AA$. The long Mn $\cdots \mathrm{Mn}$ distance in 9-3S of $\sim 4.7 \AA$ indicates the absence of a direct manganese-manganese bond. The long Mn'*F distance in 9-3S of 3.30 A indicates the absence of a direct Mn-F bond. However, each manganese atom in 9-3S has the favored 18-electron configuration.

\section{3. $\left(\mathrm{C}_{5} \mathrm{~F}_{6}\right) \mathrm{Mn}_{2}(\mathrm{CO})_{8}$}

Six structures are obtained for $\left(\mathrm{C}_{5} \mathrm{~F}_{6}\right) \mathrm{Mn}_{2}(\mathrm{CO})_{8}$ (Figure 5 and Table 3). The lowest energy $\left(\mathrm{C}_{5} \mathrm{~F}_{6}\right) \mathrm{Mn}_{2}(\mathrm{CO})_{8}$ structure 8-1S has $(\mathrm{OC})_{3} \mathrm{Mn}-\left(\mathrm{C}_{5} \mathrm{~F}_{6}\right)-\mathrm{Mn}(\mathrm{CO})_{5}$ geometry with the $\eta^{3}, \eta^{1}-\mathrm{C}_{5} \mathrm{~F}_{6}$ ring functioning as a trihapto ligand to the $\mathrm{Mn}(\mathrm{CO})_{3}$ fragment and as a monohapto ligand to the $\mathrm{Mn}(\mathrm{CO})_{5}$ fragment, as based on $\mathrm{Mn}-\mathrm{C}$ (ring) distances ranging from 2.12 to $2.16 \AA$. Similar to 9-2S, there is a dative $\mathrm{F} \rightarrow \mathrm{Mn}$ bond of length $\sim 2.20 \AA$ from a $\mathrm{CF}_{2}$ fluorine of the $\mathrm{C}_{5} \mathrm{~F}_{6}$ ring to the $\mathrm{Mn}(\mathrm{CO})_{3}$ moiety, thereby giving each manganese atom the favored 18-electron configuration.

The $\left(\mathrm{C}_{5} \mathrm{~F}_{6}\right) \mathrm{Mn}_{2}(\mathrm{CO})_{8}$ structure 8-2S, lying $8.0 \mathrm{kcal} / \mathrm{mol}(\mathrm{B} 3 \mathrm{LYP})$ or $4.0 \mathrm{kcal} / \mathrm{mol}$ (BP86) in energy above 8-1S, has the $(\mathrm{OC})_{4} \mathrm{Mn}-\left(\mathrm{C}_{5} \mathrm{~F}_{6}\right)-\mathrm{Mn}(\mathrm{CO})_{4}$ geometry unlike 8-1S (Figure 5 and Table 3). In the trans stereochemistry of $\mathbf{8 - 2 S}$, the $\eta^{3}, \eta^{1}-\mathrm{C}_{5} \mathrm{~F}_{6}$ ring is a trihapto ligand to one $\mathrm{Mn}(\mathrm{CO})_{4}$ fragment and a monohapto ligand to the other $\mathrm{Mn}(\mathrm{CO})_{4}$ fragment, based on the $\mathrm{Mn}-\mathrm{C}$ (ring) bonding distances ranging from 2.10 to $2.28 \AA$. There is also an $\mathrm{F} \rightarrow \mathrm{Mn}$ dative bond of length $\sim 2.20 \AA$ from a fluorine atom in the $\mathrm{CF}_{2}$ group of the $\mathrm{C}_{5} \mathrm{~F}_{6}$ ring to the $\mathrm{Mn}(\mathrm{CO})_{4}$ group bonded to only a single carbon atom of the $\mathrm{C}_{5} \mathrm{~F}_{6}$ ring. This gives each manganese atom the favored 18-electron configuration.

The trans $\left(\mathrm{C}_{5} \mathrm{~F}_{6}\right) \mathrm{Mn}_{2}(\mathrm{CO})_{8}$ structure 8-3S, lying $16.1 \mathrm{kcal} / \mathrm{mol}(\mathrm{B} 3 \mathrm{LYP})$ or $8.9 \mathrm{kcal} / \mathrm{mol}$ (BP86) in energy above 8-1S, like 8-2S, has $(\mathrm{OC})_{4} \mathrm{Mn}-\left(\mathrm{C}_{5} \mathrm{~F}_{6}\right)-\mathrm{Mn}(\mathrm{CO})_{4}$ geometry with an 
$\mathrm{F} \rightarrow \mathrm{Mn}$ dative bond (Figure 5 and Table 3). However, the $\mathrm{C}_{5} \mathrm{~F}_{6}$ ring is a monohapto ligand to both $\mathrm{Mn}(\mathrm{CO})_{4}$ fragments, based on the Mn-C(ring) distances of $\sim 2.10 \AA$. Thus, in 8-3S the Mn atom with an $\mathrm{F} \rightarrow \mathrm{Mn}$ dative bond has the favored 18-electron configuration, whereas the other $\mathrm{Mn}$ atom without an $\mathrm{F} \rightarrow \mathrm{Mn}$ dative bond has only a 16-electron configuration.

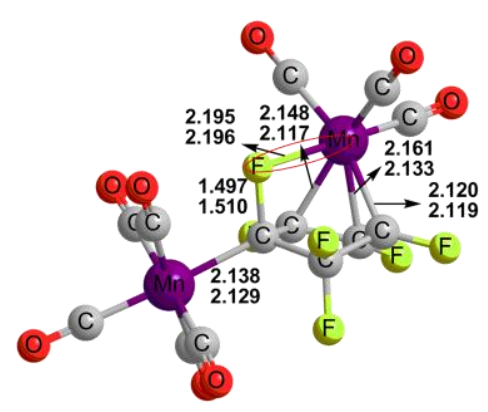

8-1S

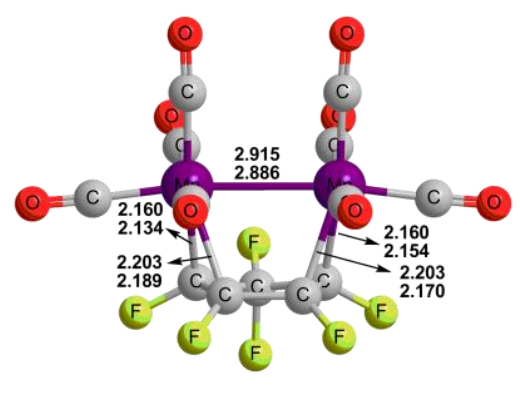

8-4S

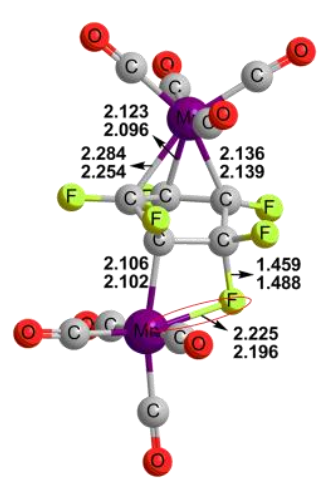

8-2S

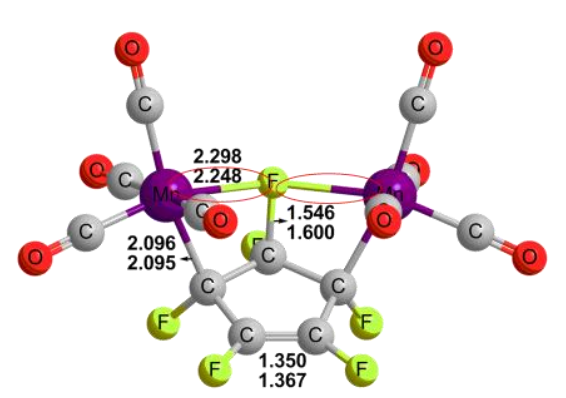

8-5S

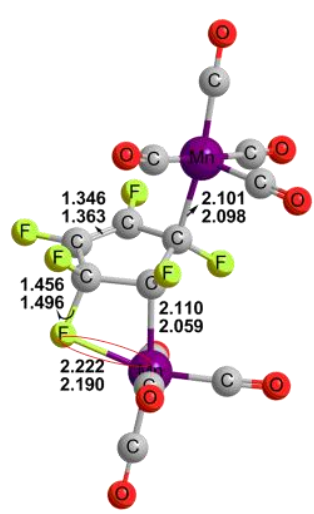

8-3S

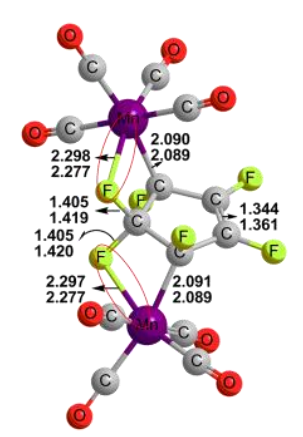

8-6S

Figure 5. Low energy $\left(\mathrm{C}_{5} \mathrm{~F}_{6}\right) \mathrm{Mn}_{2}(\mathrm{CO})_{8}$ structures. The bond distances are given in $\AA$ with the B3LYP values above and the BP86 values below. The $\mathrm{F} \rightarrow \mathrm{Mn}$ bonds in 8-1S, 8-2S, 8-3S, 8-5S, and 8-6S are indicated by ovals.

Table 3. Total energies ( $-E$ in a.u.) and relative energies $(\Delta E$ in $\mathrm{kcal} / \mathrm{mol})$ for the optimized $\left(\mathrm{C}_{5} \mathrm{~F}_{6}\right) \mathrm{Mn}_{2}(\mathrm{CO})_{8}$ structures. None of these structures has any imaginary vibrational frequencies.

\begin{tabular}{ccccc}
\hline & B3LYP & \multicolumn{2}{c}{ BP86 } \\
\hline structures & $-E$ & $\Delta E$ & $-E$ & $\Delta E$ \\
\hline $\mathbf{8 - 1 S}$ & 3998.68974 & 0.0 & 3999.15234 & 0.0 \\
$\mathbf{8 - 2 S}$ & 3998.67694 & 8.0 & 3999.14592 & 4.0 \\
$\mathbf{8 - 3 S}$ & 3998.66404 & 16.1 & 3999.13814 & 8.9 \\
$\mathbf{8 - 4 S}$ & 3998.64611 & 27.4 & 3999.13263 & 12.4 \\
$\mathbf{8 - 5 S}$ & 3998.67121 & 11.6 & 3999.12702 & 15.9 \\
$\mathbf{8 - 6 S}$ & 3998.67184 & 11.2 & 3999.12649 & 16.2 \\
\hline
\end{tabular}


The $\left(\mathrm{C}_{5} \mathrm{~F}_{6}\right) \mathrm{Mn}_{2}(\mathrm{CO})_{8}$ structure 8-4S, lying $27.4 \mathrm{kcal} / \mathrm{mol}(\mathrm{B} 3 \mathrm{LYP})$ or $12.4 \mathrm{kcal} / \mathrm{mol}$ (BP86) in energy above 8-1S, has a bis(dihapto) $\mathrm{C}_{5} \mathrm{~F}_{6}$ ligand, based on $\mathrm{Mn}-\mathrm{C}$ (ring) bonding distances ranging from 2.13 to $2.20 \AA$ (Figure 5 and Table 3). The closest Mn*F ${ }^{\circ}$ distance in 8-4S of $\sim 3.05 \AA$ indicates the absence of a direct Mn-F bond. The Mn-Mn distance of $2.915 \AA$ (B3LYP) or $2.886 \AA$ (BP86) in $\mathbf{8 - 4 S}$ is similar to the experimental Mn-Mn single bond distance of $2.895 \AA$ in $\mathrm{Mn}_{2}(\mathrm{CO})_{10}$ obtained from the most recent X-ray crystallography study. ${ }^{48}$ This suggests a formal single bond similar to that in $\mathrm{Mn}_{2}(\mathrm{CO})_{10}$ thereby giving each manganese atom in 8-4S the favored 18-electron configuration.

The $\left(\mathrm{C}_{5} \mathrm{~F}_{6}\right) \mathrm{Mn}_{2}(\mathrm{CO})_{8}$ structure 8-5S is a $(\mathrm{OC})_{4} \mathrm{Mn}-\left(\mathrm{C}_{5} \mathrm{~F}_{6}\right)-\mathrm{Mn}(\mathrm{CO})_{4}$ structure with the two manganese atoms bridged by one of the $\mathrm{CF}_{2}$ fluorine atoms of the $\mathrm{C}_{5} \mathrm{~F}_{6}$ ring (Figure 5 and Table 3). The $\mathrm{C}_{5} \mathrm{~F}_{6}$ ring is a monohapto ligand with respect to each $\mathrm{Mn}(\mathrm{CO})_{4}$ fragment, based on $\mathrm{Mn}-\mathrm{C}$ (ring) distances of $\sim 2.30 \AA$. The long $\mathrm{Mn} \cdots \mathrm{Mn}$ distance of $\sim 4.3 \AA$ in 8-5S indicates the lack of a direct manganese-manganese bond. However, the $\mathrm{CF}_{2}$ bridging $\mathrm{F}$ atom in 8-5S donates a lone pair to each manganese atom through dative $\mathrm{F} \rightarrow \mathrm{Mn}$ bonds of length $\sim 2.27 \AA$. This gives each manganese atom in 8-5S the favored 18-electron configuration.

The trans $\left(\mathrm{C}_{5} \mathrm{~F}_{6}\right) \mathrm{Mn}_{2}(\mathrm{CO})_{8}$ structure 8-6S, lying $11.2 \mathrm{kcal} / \mathrm{mol}(\mathrm{B} 3 \mathrm{LYP})$ or $16.2 \mathrm{kcal} / \mathrm{mol}$ (BP86) in energy above 8-1S, has the $\mathrm{C}_{5} \mathrm{~F}_{6}$ ring functioning as a monohapto ligand to each $\mathrm{Mn}(\mathrm{CO})_{4}$ fragment, based on the $\mathrm{Mn}-\mathrm{C}$ (ring) bonding distances of $\sim 2.10 \AA$ (Figure 5 and Table 3). This leaves an uncomplexed $\mathrm{C}=\mathrm{C}$ double bond of length $\sim 1.35 \AA$. Each fluorine atom in the $\mathrm{CF}_{2}$ group of the $\mathrm{C}_{5} \mathrm{~F}_{6}$ rings forms a dative $\mathrm{F} \rightarrow \mathrm{Mn}$ bond of length $\sim 2.30 \AA$ to one of the manganese atoms in 8-6S. This gives each manganese atom the favored 18-electron configuration.

In the above five $\left(\mathrm{C}_{5} \mathrm{~F}_{6}\right) \mathrm{Mn}_{2}(\mathrm{CO})_{8}$ structures containing direct $\mathrm{F} \rightarrow \mathrm{Mn}$ bonds, namely 8-1S, 8-2S, 8-3S, 8-5S, and 8-6S, the corresponding C-F bonds are lengthened by 0.03 to $0.23 \AA$ (Table S37), suggesting C-F bond activation.

\section{4. $\left(\mathrm{C}_{5} \mathrm{~F}_{6}\right) \mathrm{Mn}_{2}(\mathrm{CO})_{7}$}

Five singlet $\left(\mathrm{C}_{5} \mathrm{~F}_{6}\right) \mathrm{Mn}_{2}(\mathrm{CO})_{7}$ structures were found (Figure 6 and Table 4). Triplet $\left(\mathrm{C}_{5} \mathrm{~F}_{6}\right) \mathrm{Mn}_{2}(\mathrm{CO})_{7}$ structures lie at least $10 \mathrm{kcal} / \mathrm{mol}$ above the lowest singlet isomer and thus are not reported in the present paper. The lowest energy $\left(\mathrm{C}_{5} \mathrm{~F}_{6}\right) \mathrm{Mn}_{2}(\mathrm{CO})_{7}$ structure 7-1S has the $\mathrm{Mn}(\mathrm{CO})_{3}$ and $\mathrm{Mn}(\mathrm{CO})_{4}$ fragments in trans positions relative to the $\eta^{3}, \eta^{1}-\mathrm{C}_{5} \mathrm{~F}_{6}$ ring, which is a trihapto ligand to the $\mathrm{Mn}(\mathrm{CO})_{3}$ fragment and a monohapto ligand to the $\mathrm{Mn}(\mathrm{CO})_{4}$ fragment, as indicated by $\mathrm{Mn}-\mathrm{C}$ (ring) bonding distances ranging from 2.07 to $2.16 \AA$. In 7-1S there is an $\mathrm{F} \rightarrow \mathrm{Mn}$ dative bond to each manganese atom with $\mathrm{Mn}-\mathrm{F}$ distances of 2.2 to $2.4 \AA$. This gives each manganese atom the favored 18-electron configuration. 


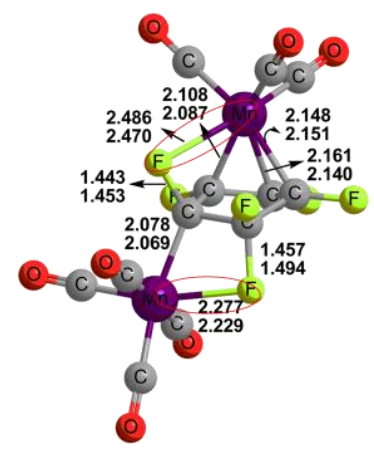

7-1S

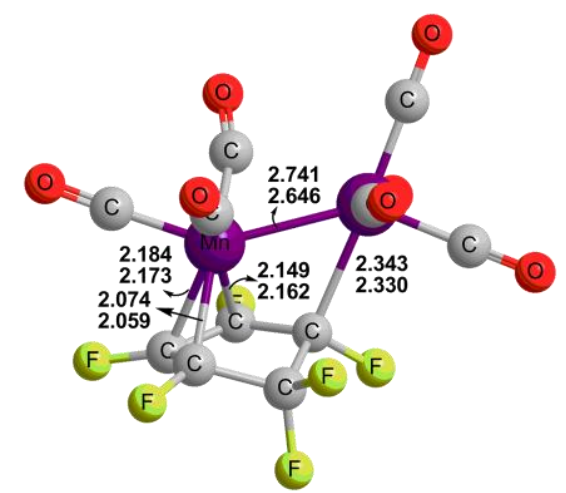

7-2S

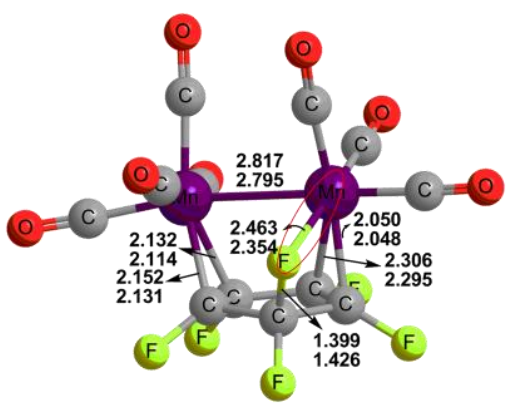

7-3S

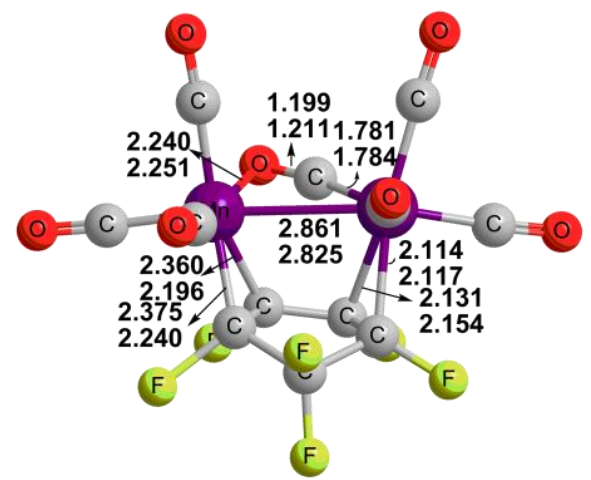

7-4S

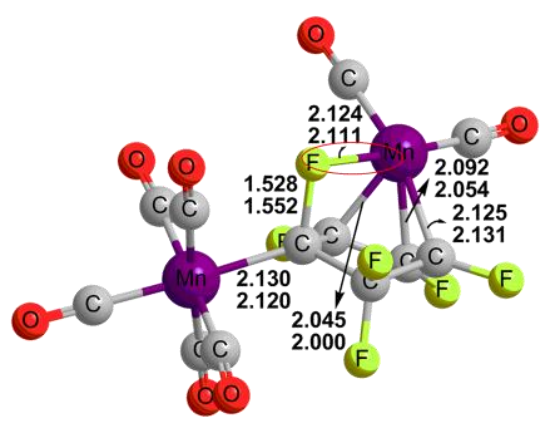

7-5S

Figure 6. Low-energy $\left(\mathrm{C}_{5} \mathrm{~F}_{6}\right) \mathrm{Mn}_{2}(\mathrm{CO})_{7}$ structures. The bond distances are given in $\AA$ with the B3LYP values above and the BP86 values below. The $\mathrm{F} \rightarrow \mathrm{Mn}$ bonds in structure 7-1S, 7-3S, and 7-5S are highlighted by ovals.

Table 4. Total energies ( $-E$ in a.u.) and relative energies ( $\Delta E$ in $\mathrm{kcal} / \mathrm{mol}$ ) for the optimized $\left(\mathrm{C}_{5} \mathrm{~F}_{6}\right) \mathrm{Mn}_{2}(\mathrm{CO})_{7}$ structures. None of the structures has any imaginary vibrational frequencies

\begin{tabular}{ccc|cc}
\hline \multicolumn{3}{c|}{ B3LYP } & \multicolumn{2}{c}{ BP86 } \\
\hline & $-E$ & $\Delta E$ & $-E$ & $\Delta E$ \\
\hline $\mathbf{7 - 1 S}$ & 3885.31256 & 0.0 & 3885.76814 & 0.0 \\
$\mathbf{7 - 2 S}$ & 3885.29778 & 9.3 & 3885.76577 & 1.5 \\
$\mathbf{7 - 3 S}$ & 3885.27468 & 23.8 & 3885.75282 & 9.6 \\
$\mathbf{7 - 4 S}$ & 3885.27553 & 23.2 & 3885.75277 & 9.6 \\
$\mathbf{7 - 5 S}$ & 3885.28967 & 14.4 & 3885.74383 & 15.3 \\
\hline
\end{tabular}

The cis- $\left(\mathrm{C}_{5} \mathrm{~F}_{6}\right) \mathrm{Mn}_{2}(\mathrm{CO})_{7}$ structure 7-2S, lying $9.3 \mathrm{kcal} / \mathrm{mol}(\mathrm{B} 3 \mathrm{LYP}$ ) or $1.5 \mathrm{kcal} / \mathrm{mol}$ (BP86) in energy above 7-1S, has an $\eta^{3}, \eta^{1}-\mathrm{C}_{5} \mathrm{~F}_{6}$ ring, bonded as a trihapto ligand to the $\mathrm{Mn}(\mathrm{CO})_{3}$ fragment and as a monohapto ligand to the $\mathrm{Mn}(\mathrm{CO})_{4}$ fragment, as inferred from the $\mathrm{Mn}-\mathrm{C}$ (ring) bonding distances from 2.06 to $2.34 \AA$ (Figure 6 and Table 4). The Mn $\rightarrow$ Mn distance of 
$2.741 \AA$ (B3LYP) or $2.646 \AA$ (BP86) in 7-2S can be interpreted as a dative bond. The long Mn'*F distance in 7-2S of $~ 3.00 \AA$ indicates the absence of a direct Mn-F bond. This gives one manganese atom the favored 18-electron configuration but the other manganese atom only a 16-electron configuration.

The cis- $\left(\mathrm{C}_{5} \mathrm{~F}_{6}\right) \mathrm{Mn}_{2}(\mathrm{CO})_{7}$ structure 7-3S, lying $23.8 \mathrm{kcal} / \mathrm{mol}(\mathrm{B} 3 \mathrm{LYP})$ or $9.6 \mathrm{kcal} / \mathrm{mol}$ (BP86) in energy above 7-1S, has the $\eta^{2}, \eta^{2}-\mathrm{C}_{5} \mathrm{~F}_{6}$ ring bonded as a dihapto ligand to both the $\mathrm{Mn}(\mathrm{CO})_{4}$ and the $\mathrm{Mn}(\mathrm{CO})_{3}$ fragments, as indicated by the $\mathrm{Mn}-\mathrm{C}$ (ring) bond distances ranging from 2.05 to $2.30 \AA$ (Figure 6 and Table 4). In 7-3S there is a $\mathrm{F} \rightarrow \mathrm{Mn}$ dative bond of length $\sim 2.4 \AA$ from a $\mathrm{CF}_{2}$ fluorine atom to the manganese atom in the $\mathrm{Mn}(\mathrm{CO})_{3}$ fragment. The Mn-Mn distance of $2.817 \AA$ (B3LYP) or $2.795 \AA$ (BP86) suggests the formal single bond, required to give each manganese atom the favored 18-electron configuration.

The cis $\left(\mathrm{C}_{5} \mathrm{~F}_{6}\right) \mathrm{Mn}_{2}(\mathrm{CO})_{7}$ structure $7-4 \mathrm{~S}$, lying $23.2 \mathrm{kcal} / \mathrm{mol}(\mathrm{B} 3 \mathrm{LYP})$ or $9.6 \mathrm{kcal} / \mathrm{mol}$ (BP86) in energy above 7-1S, has six terminal CO groups (three for each Mn atom) and one four electron donor $\eta^{2}-\mu-\mathrm{CO}$ group bridging the two manganese atoms, as indicated by a short $\mathrm{Mn}-\mathrm{O}$ distance of $\sim 2.25 \AA$ to this CO group (Figure 6 and Table 4). The $\eta^{2}, \eta^{2}-C_{5} \mathrm{~F}_{6}$ ring is bonded to each manganese atom as a dihapto ligand, as indicated by $\mathrm{Mn}-\mathrm{C}$ (ring) bonding distances ranging from 2.11 to $2.38 \AA$. The long $\mathrm{Mn}{ }^{\cdots} \mathrm{F}$ distance in 7-4S of $\sim 3.00 \AA$ indicates the absence of a direct Mn-F bond. The Mn-Mn distance of $2.861 \AA$ (B3LYP) or $2.825 \AA$ (BP86) in 7-4S corresponds to a formal single bond, thereby giving each manganese atom the favored 18-electron configuration.

The trans $\left(\mathrm{C}_{5} \mathrm{~F}_{6}\right) \mathrm{Mn}_{2}(\mathrm{CO})_{7}$ structure 7-5S, lying $14.4 \mathrm{kcal} / \mathrm{mol}(\mathrm{B} 3 \mathrm{LYP})$ or $15.3 \mathrm{kcal} / \mathrm{mol}$ (BP86) in energy above 7-1S, has the carbonyl groups very unevenly distributed to give $\mathrm{Mn}(\mathrm{CO})_{2}$ and $\mathrm{Mn}(\mathrm{CO})_{5}$ fragments (Figure 6 and Table 4). The $\eta^{3}, \eta^{1}-\mathrm{C}_{5} \mathrm{~F}_{6}$ ring in 7-5S is a trihapto ligand to the $\mathrm{Mn}(\mathrm{CO})_{2}$ fragment and a monohapto ligand to the $\mathrm{Mn}(\mathrm{CO})_{5}$ fragment. There is an $\mathrm{F} \rightarrow \mathrm{Mn}$ dative bond to the $\mathrm{Mn}(\mathrm{CO})_{2}$ moiety with an $\mathrm{Mn}-\mathrm{F}$ distance of $2.1 \AA$. The manganese atom in the $\mathrm{Mn}(\mathrm{CO})_{5}$ fragment has the favored 18-electron configuration, while the manganese atom in the $\mathrm{Mn}(\mathrm{CO})_{2}$ fragment has only a 16-electron configuration.

In the $\left(\mathrm{C}_{5} \mathrm{~F}_{6}\right) \mathrm{Mn}_{2}(\mathrm{CO})_{7}$ structures with $\mathrm{F} \rightarrow \mathrm{Mn}$ bonds, namely 7-1S, 7-3S, and 7-5S, the corresponding C-F bonds are lengthened by 0.03 to $0.23 \AA$ (Table S37), suggesting C-F bond activation.

\subsection{Natural bond orbital (NBO) analysis}

Table 5 lists the Mn-Mn distances, the Wiberg Bond Indices (WBIs) for the Mn-Mn bonds, and the natural charges obtained by natural bonding orbital (NBO) analysis ${ }^{49}$ for the two manganese atoms in the singlet $\left(\mathrm{C}_{5} \mathrm{~F}_{6}\right) \mathrm{Mn}_{2}(\mathrm{CO})_{n}$. The $\mathrm{Mn}-\mathrm{Mn}$ bond lengths in the cis structures range from 2.65 to $2.91 \AA$ but their WBIs fall in the narrow range from 0.14 to 0.18 . This 
suggests that all of the $\mathrm{Mn}-\mathrm{Mn}$ bonds in these structures are formal single bonds. In contrast, the $\mathrm{Mn}-\mathrm{Mn}$ non-bonding interactions in the other $\left(\mathrm{C}_{5} \mathrm{~F}_{6}\right) \mathrm{Mn}_{2}(\mathrm{CO})_{n}(n=10,9,8,7)$ structures, such as the trans isomers, have WBI values lower than 0.02 .

Table 5. The Mn-Mn distances, Wiberg Bond Indices (WBI) for the $\mathrm{Mn}-\mathrm{Mn}$ bonds, and natural charges for the two $\mathrm{Mn}$ atoms in the singlet binuclear $\left(\mathrm{C}_{5} \mathrm{~F}_{6}\right) \mathrm{Mn}_{2}(\mathrm{CO})_{n}(n=10,9,8,7)$

\begin{tabular}{cccccccc}
\hline \multirow{2}{*}{ Structure } & \multicolumn{2}{c}{$\begin{array}{c}\text { Mn-Mn } \\
\text { distance }(\AA)\end{array}$} & \multicolumn{2}{c}{ WBI } & \multicolumn{2}{c}{$\begin{array}{c}\text { Natural charges } \\
\text { on the metal atoms }\end{array}$} & $\begin{array}{c}\text { Formal } \\
\text { Mn-Mn } \\
\text { bond order }\end{array}$ \\
\hline & B3LYP & BP86 & B3LYP & BP86 & B3LYP & BP86 & \\
\hline $\mathbf{1 0 - 1 S}$ & 6.154 & 6.163 & 0.00 & 0.00 & $-0.41 /-0.33$ & $-0.52 /-0.44$ & 0 \\
$\mathbf{1 0 - 2 S}$ & 6.326 & 6.310 & 0.00 & 0.00 & $-0.40 /-0.40$ & $-0.51 /-0.51$ & 0 \\
$\mathbf{1 0 - 3 S}$ & 5.256 & 5.247 & 0.01 & 0.01 & $-0.32 /-0.35$ & $-0.44 /-0.47$ & 0 \\
$\mathbf{1 0 - 4 S}$ & 4.677 & 4.629 & 0.00 & 0.00 & $-0.32 /-0.47$ & $-0.43 /-0.58$ & 0 \\
$\mathbf{9 - 1 S}$ & 5.218 & 5.194 & 0.01 & 0.02 & $-0.32 /-0.37$ & $-0.44 /-0.42$ & 0 \\
$\mathbf{9 - 2 S}$ & 5.943 & 5.932 & 0.00 & 0.00 & $-0.39 /-0.16$ & $-0.50 /-0.24$ & 0 \\
$\mathbf{9 - 3 S}$ & 4.676 & 4.684 & 0.01 & 0.01 & $-0.48 /-0.28$ & $-0.57 /-0.38$ & 0 \\
$\mathbf{8 - 1 S}$ & 4.674 & 4.651 & 0.01 & 0.01 & $-0.23 /-0.20$ & $-0.35 /-0.25$ & 0 \\
$\mathbf{8 - 2 S}$ & 5.055 & 5.016 & 0.01 & 0.02 & $-0.13 /-0.37$ & $-0.22 /-0.42$ & 0 \\
$\mathbf{8 - 3 S}$ & 5.163 & 4.949 & 0.01 & 0.01 & $-0.11 /-0.14$ & $-0.09 /-0.21$ & 0 \\
$\mathbf{8 - 4 S}$ & 2.915 & 2.886 & 0.16 & 0.14 & $-0.79 /-0.79$ & $-0.81 /-0.80$ & 1 \\
$\mathbf{8 - 5 S}$ & 4.384 & 4.258 & 0.01 & 0.01 & $-0.18 /-0.18$ & $-0.25 /-0.25$ & 0 \\
$\mathbf{8 - 6 S}$ & 5.452 & 5.420 & 0.00 & 0.01 & $-0.16 /-0.17$ & $-0.24 /-0.24$ & 0 \\
$\mathbf{7 - 1 S}$ & 4.680 & 4.635 & 0.01 & 0.01 & $-0.05 /-0.18$ & $-0.14 /-0.23$ & 0 \\
$\mathbf{7 - 2 S}$ & 2.741 & 2.646 & 0.16 & 0.18 & $-0.59 /-0.60$ & $-0.59 /-0.73$ & 1 \\
$\mathbf{7 - 3 S}$ & 2.817 & 2.795 & 0.17 & 0.16 & $-0.81 /-0.44$ & $-0.82 /-0.50$ & 1 \\
$\mathbf{7 - 4 S}$ & 2.861 & 2.852 & 0.16 & 0.16 & $-0.47 /-0.72$ & $-0.56 /-0.72$ & 1 \\
$\mathbf{7 - 5 S}$ & 4.583 & 4.544 & 0.01 & 0.02 & $-0.22 /-0.01$ & $-0.34 /-0.05$ & 0 \\
\hline
\end{tabular}

The natural charges on the manganese atoms in the binuclear complexes $\left(\mathrm{C}_{5} \mathrm{~F}_{6}\right) \mathrm{Mn}_{2}(\mathrm{CO})_{n}$ $(n=8,7)$ become more negative with increasing numbers of $\mathrm{CO}$ groups. These observations imply that the $\pi$ back-bonding of a metal atom to a $\mathrm{CO}$ group is not strong enough to compensate for the negative charge introduced by the $\sigma$ forward bonding from the carbon lone pair of $\mathrm{CO}$ to the manganese atom. For example, the natural atomic charges on the manganese atoms bonded to four CO groups, such as both manganese atoms in $\mathbf{8 - 4 S}$, the left manganese atom in 7-3S, and the right manganese atoms in 7-2S and 7-4S (Figure 5) are -0.7 to -0.8 . The natural atomic charges on the manganese atoms bonded to only three $\mathrm{CO}$ groups, such as on manganese atom in 7-2S, 7-3S and 7-4S, are significantly less negative at -0.5 to -0.6 . 


\subsection{Thermochemistry}

3.6.1. Dissociation energies. Table 6 lists energies for $\mathrm{CO}$ dissociation from binuclear $\left(\mathrm{C}_{5} \mathrm{~F}_{6}\right) \mathrm{Mn}_{2}(\mathrm{CO})_{n}(n=10,9,8,7)$ complexes based on their lowest energy structures. All of the $\mathrm{CO}$ group dissociation energies are seen to be significant, ranging from 16.2 to $30.4 \mathrm{kcal} / \mathrm{mol}$ (B3LYP) or from 25.9 to $35.7 \mathrm{kcal} / \mathrm{mol}$ (BP86). These values are comparable to the experimental values of 27,41 , and $37 \mathrm{kcal} / \mathrm{mol}$ for the binary carbonyls $\mathrm{Ni}(\mathrm{CO})_{4}, \mathrm{Fe}(\mathrm{CO})_{5}$, and $\mathrm{Cr}(\mathrm{CO})_{6}$, respectively. ${ }^{50}$ These $\mathrm{CO}$ dissociation energies suggest that all of the species reported in this paper are viable with respect to $\mathrm{CO}$ dissociation.

Table 6. Energies $(\mathrm{kcal} / \mathrm{mol})$ for the successive dissociation of carbonyl groups from the lowest energy $\left(\mathrm{C}_{5} \mathrm{~F}_{6}\right) \mathrm{Mn}_{2}(\mathrm{CO})_{n}(n=10,9,8,7)$ structures.

\begin{tabular}{ccc}
\hline & B3LYP & BP86 \\
\hline$\left(\mathrm{C}_{5} \mathrm{~F}_{6}\right) \mathrm{Mn}_{2}(\mathrm{CO})_{10} \rightarrow\left(\mathrm{C}_{5} \mathrm{~F}_{6}\right) \mathrm{Mn}_{2}(\mathrm{CO})_{9}+\mathrm{CO}$ & 30.4 & 26.8 \\
$\left(\mathrm{C}_{5} \mathrm{~F}_{6}\right) \mathrm{Mn}_{2}(\mathrm{CO})_{9} \rightarrow\left(\mathrm{C}_{5} \mathrm{~F}_{6}\right) \mathrm{Mn}_{2}(\mathrm{CO})_{8}+\mathrm{CO}$ & 16.2 & 25.9 \\
$\left.\left(\mathrm{C}_{5} \mathrm{~F}_{6}\right) \mathrm{Mn}_{2}(\mathrm{CO})_{8} \rightarrow \mathrm{C}_{5} \mathrm{~F}_{6}\right) \mathrm{Mn}_{2}(\mathrm{CO})_{7}+\mathrm{CO}$ & 30.4 & 35.7 \\
\hline
\end{tabular}

3.6.2. Complexation energies and synthetic prospects. The complexation energies for $\mathrm{C}_{5} \mathrm{~F}_{6}$ and the binuclear homoleptic carbonyl fragments to form the binuclear $\left(\mathrm{C}_{5} \mathrm{~F}_{6}\right) \mathrm{Mn}_{2}(\mathrm{CO})_{n}(n=10,9,8$, 7) structures based on the following reactions are listed in Table 7.

$$
\mathrm{Mn}_{2}(\mathrm{CO})_{n}+\mathrm{C}_{5} \mathrm{~F}_{6} \rightarrow\left(\mathrm{C}_{5} \mathrm{~F}_{6}\right) \mathrm{Mn}_{2}(\mathrm{CO})_{n}
$$

For comparison, the similar complexation energies for the stable binuclear $\left(\mathrm{C}_{5} \mathrm{~F}_{6}\right) \mathrm{Fe}_{2}(\mathrm{CO})_{8}$ and $\left(\mathrm{C}_{5} \mathrm{~F}_{6}\right) \mathrm{Co}_{2}(\mathrm{CO})_{7}$, which have been synthesized, ${ }^{11,12}$ have been calculated at the same level of theory and are also listed in Table 7 . The complexation energies of $\left(\mathrm{C}_{5} \mathrm{~F}_{6}\right) \mathrm{Fe}_{2}(\mathrm{CO})_{8}$ and $\left(\mathrm{C}_{5} \mathrm{~F}_{6}\right) \mathrm{Co}_{2}(\mathrm{CO})_{7}$ are -37.4 and $-20.9 \mathrm{kcal} / \mathrm{mol}(\mathrm{B} 3 \mathrm{LYP})$, or -29.8 and $-25.7 \mathrm{kcal} / \mathrm{mol}(\mathrm{BP} 86)$, respectively. The complexation energy of $\left(\mathrm{C}_{5} \mathrm{~F}_{6}\right) \mathrm{Mn}_{2}(\mathrm{CO})_{8}$ of $-30.2 \mathrm{kcal} / \mathrm{mol}(\mathrm{B} 3 \mathrm{LYP})$ or -29.4 $\mathrm{kcal} / \mathrm{mol}$ (BP86) is thus comparable to that of the iron and cobalt derivatives. The complexation energy of $\left(\mathrm{C}_{5} \mathrm{~F}_{6}\right) \mathrm{Mn}_{2}(\mathrm{CO})_{7}$ is significantly larger at $-45.2 \mathrm{kcal} / \mathrm{mol}(\mathrm{B} 3 \mathrm{LYP})$ or $-41.4 \mathrm{kcal} / \mathrm{mol}$ (BP86). However, the complexation energies for $\left(\mathrm{C}_{5} \mathrm{~F}_{6}\right) \mathrm{Mn}_{2}(\mathrm{CO})_{10}$ and $\left(\mathrm{C}_{5} \mathrm{~F}_{6}\right) \mathrm{Mn}_{2}(\mathrm{CO})_{9}$ are relatively smaller.

None of the compounds discussed in this paper has been synthesized. However, thermochemical information suggest $\left(\mathrm{C}_{5} \mathrm{~F}_{6}\right) \mathrm{Mn}_{2}(\mathrm{CO})_{8}$ and $\left(\mathrm{C}_{5} \mathrm{~F}_{6}\right) \mathrm{Mn}_{2}(\mathrm{CO})_{7}$ to be promising synthetic targets. Possible synthetic methods could include reactions of hexafluorocyclopentadiene with manganese carbonyl derivatives containing readily displaced ligands such as the acetonitrile complexes $\left(\mathrm{CH}_{3} \mathrm{CN}\right)_{n} \mathrm{Mn}_{2}(\mathrm{CO})_{10-n}(n=1,2) .{ }^{51}$ Reaction of $\mathrm{Mn}_{2}(\mathrm{CO})_{10}$ with hexafluorocyclopentadiene might require temperatures higher than the polymerization temperature of hexafluorocyclopentadiene. However, use of trimethylamine $\mathrm{N}$-oxide to facilitate $\mathrm{CO}$ loss from $\mathrm{Mn}_{2}(\mathrm{CO})_{10}$ 
might facilitate formation of a $\left(\mathrm{C}_{5} \mathrm{~F}_{6}\right) \mathrm{Mn}_{2}(\mathrm{CO})_{n}$ derivative under conditions mild enough for hexafluorocyclopentadiene to be a viable reagent.

Table 7. Complexation energies (in kcal/mol) for $\left(\mathrm{C}_{5} \mathrm{~F}_{6}\right) \mathrm{Mn}_{2}(\mathrm{CO})_{n}(n=10,9,8,7)$. Those for the analogous $\left(\mathrm{C}_{5} \mathrm{~F}_{6}\right) \mathrm{Fe}_{2}(\mathrm{CO})_{8}$ and $\left(\mathrm{C}_{5} \mathrm{~F}_{6}\right) \mathrm{Co}_{2}(\mathrm{CO})_{7}$ are also listed for comparison.

\begin{tabular}{lll}
\hline & B3LYP & BP86 \\
\hline $\mathrm{Fe}_{2}(\mathrm{CO})_{8}+\mathrm{C}_{5} \mathrm{~F}_{6} \rightarrow\left(\mathrm{C}_{5} \mathrm{~F}_{6}\right) \mathrm{Fe}_{2}(\mathrm{CO})_{8}$ & -37.4 & -29.8 \\
$\mathrm{Co}_{2}(\mathrm{CO})_{7}+\mathrm{C}_{5} \mathrm{~F}_{6} \rightarrow\left(\mathrm{C}_{5} \mathrm{~F}_{6}\right) \mathrm{Co}_{2}(\mathrm{CO})_{7}$ & -20.9 & -25.7 \\
\hline $\mathrm{Mn}_{2}(\mathrm{CO})_{10}+\mathrm{C}_{5} \mathrm{~F}_{6} \rightarrow\left(\mathrm{C}_{5} \mathrm{~F}_{6}\right) \mathrm{Mn}_{2}(\mathrm{CO})_{10}$ & -10.9 & -5.8 \\
$\mathrm{Mn}_{2}(\mathrm{CO})_{9}+\mathrm{C}_{5} \mathrm{~F}_{6} \rightarrow\left(\mathrm{C}_{5} \mathrm{~F}_{6}\right) \mathrm{Mn}_{2}(\mathrm{CO})_{9}$ & -12.8 & -15.7 \\
$\mathrm{Mn}_{2}(\mathrm{CO})_{8}+\mathrm{C}_{5} \mathrm{~F}_{6} \rightarrow\left(\mathrm{C}_{5} \mathrm{~F}_{6}\right) \mathrm{Mn}_{2}(\mathrm{CO})_{8}$ & -30.2 & -29.4 \\
$\mathrm{Mn}_{2}(\mathrm{CO})_{7}+\mathrm{C}_{5} \mathrm{~F}_{6} \rightarrow\left(\mathrm{C}_{5} \mathrm{~F}_{6}\right) \mathrm{Mn}_{2}(\mathrm{CO})_{7}$ & -45.2 & -41.4 \\
\hline
\end{tabular}

\section{Conclusions}

The low-energy $\left(\mathrm{C}_{5} \mathrm{~F}_{6}\right) \mathrm{Mn}_{2}(\mathrm{CO})_{10}$ structures all have $\mathrm{Mn}(\mathrm{CO})_{5}$ units bonded to $\mathrm{sp}^{2}$ carbon atoms in the $\mathrm{C}_{5} \mathrm{~F}_{6}$ ring, leaving an uncomplexed $\mathrm{C}=\mathrm{C}$ double bond of length $\sim 1.35 \AA$ (Figure 2). Structures with the $\mathrm{Mn}(\mathrm{CO})_{5}$ units on non-adjacent carbon atoms and/or opposite sides of the $\mathrm{C}_{5} \mathrm{~F}_{6}$ ring are of lower energy than the isomeric structures with the $\mathrm{Mn}(\mathrm{CO})_{5}$ units on adjacent carbon atoms and/or the same side of the $\mathrm{C}_{5} \mathrm{~F}_{6}$ ring, apparently for steric reasons.

None of the low-energy $\left(\mathrm{C}_{5} \mathrm{~F}_{6}\right) \mathrm{Mn}_{2}(\mathrm{CO})_{9}$ structures has a sufficiently short $\mathrm{Mn}{ }^{\cdots} \mathrm{Mn}$ distance to suggest a direct manganese-manganese bond. In all of the three lowest-energy $\left(\mathrm{C}_{5} \mathrm{~F}_{6}\right) \mathrm{Mn}_{2}(\mathrm{CO})_{9}$ structures (Figure 3) an $\mathrm{Mn}(\mathrm{CO})_{5}$ unit is bonded to one of the $\mathrm{sp}^{2}$ carbon atoms of the $\mathrm{C}_{5} \mathrm{~F}_{6}$ ring. The $\left(\mathrm{C}_{5} \mathrm{~F}_{6}\right) \mathrm{Mn}_{2}(\mathrm{CO})_{9}$ structures with the $\mathrm{C}_{5} \mathrm{~F}_{6}$ ring bonded to an $\mathrm{Mn}(\mathrm{CO})_{4}$ unit as a trihapto ligand (9-1S) and with the $\mathrm{C}_{5} \mathrm{~F}_{6}$ ligand functioning as a bidentate chelating ligand forming an $\mathrm{C}-\mathrm{Mn}$ bond and an $\mathrm{F} \rightarrow \mathrm{Mn}$ dative bond from the $\mathrm{CF}_{2}$ group (9-2S) have similar energies (Table 2). A somewhat higher energy $\left(\mathrm{C}_{5} \mathrm{~F}_{6}\right) \mathrm{Mn}_{2}(\mathrm{CO})_{9}$ structure (9-3S) has a $\mathrm{CO}$ group of the $\mathrm{Mn}(\mathrm{CO})_{5}$ unit bonded to the $\mathrm{Mn}(\mathrm{CO})_{4}$ unit through an $\mathrm{O} \rightarrow \mathrm{Mn}$ dative bond. This $\mathrm{CO}$ group is an unusual type of four-electron donor $\mathrm{CO}$ group since it does not bridge a metal-metal bond.

The lowest-energy structures for the more highly unsaturated $\left(\mathrm{C}_{5} \mathrm{~F}_{6}\right) \mathrm{Mn}_{2}(\mathrm{CO})_{8}$ still do not contain an Mn-Mn bond. In the three lowest energy $\left(\mathrm{C}_{5} \mathrm{~F}_{6}\right) \mathrm{Mn}_{2}(\mathrm{CO})_{8}$ structures (Figure 4) the $\mathrm{C}_{5} \mathrm{~F}_{6}$ ligand donates a total of six electrons to the $\mathrm{Mn}_{2}(\mathrm{CO})_{8}$ unit. In these structures the combination of an $\mathrm{Mn}-\mathrm{C} \sigma$-bond with one manganese atom and trihapto coordination to the other manganese atom using the remaining three ligand $\mathrm{sp}^{2}$ carbons is supplemented by a $\mathrm{F} \rightarrow \mathrm{Mn}$ 
dative bond. Only one of the higher energy $\left(\mathrm{C}_{5} \mathrm{~F}_{6}\right) \mathrm{Mn}_{2}(\mathrm{CO})_{8}$ structures (8-4S) has a $\mathrm{Mn}-\mathrm{Mn}$ bond. Other $\left(\mathrm{C}_{5} \mathrm{~F}_{6}\right) \mathrm{Mn}_{2}(\mathrm{CO})_{8}$ structures have a fluorine atom bridging the $\mathrm{Mn}_{2}$ unit by forming an $\mathrm{F} \rightarrow \mathrm{Mn}$ dative bond with each manganese atom (8-5S) or utilize both $\mathrm{CF}_{2}$ fluorine atoms to form $\mathrm{F} \rightarrow$ Mn dative bonds with each manganese atom (8-6S).

Even the lowest energy structure 7-1S for the still more highly unsaturated $\left(\mathrm{C}_{5} \mathrm{~F}_{6}\right) \mathrm{Mn}_{2}(\mathrm{CO})_{7}$ does not have a $\mathrm{Mn}-\mathrm{Mn}$ bond. Instead trihapto bonding of the $\mathrm{C}_{5} \mathrm{~F}_{6}$ ligand plus an $\mathrm{F} \rightarrow \mathrm{Mn}$ dative bond to an $\mathrm{Mn}(\mathrm{CO})_{3}$ unit combined with monohapto $\mathrm{C}_{5} \mathrm{~F}_{6}$ bonding plus an $\mathrm{F} \rightarrow \mathrm{Mn}$ dative bond to an $\mathrm{Mn}(\mathrm{CO})_{4}$ unit is sufficient to give each manganese atom the favored 18-electron configuration.

Acknowledgment. We are indebted to the National Natural Science Foundation of China (21273082), the Training Plan of Guangdong Province Outstanding Young Teachers in Higher Education Institutions (HS20150003), the U. S. National Science Foundation (Grant CHE1057466), and Special Program for Applied Research on Super Computation of the NSFCGuangdong Joint Fund (the second phase) for support of this research. 


\section{Literature References}

1 F. Calderazzo, in Encyclopedia of Inorganic Chemistry, $2^{\text {nd }}$ Edition, ed. King, R. B., Wiley, Chichester, 2005, pp. 764-781.

2 J. F. Nixon, Adv. Inorg. Chem. 29 (1985) 41-141.

3 K. F. Watterson, G. Wilkinson, Chem. and Ind. (1959) 991.

$4 \quad$ K. F. Watterson, G. Wilkinson, Chem. and Ind. (1960) 1358.

$5 \quad$ H. H. Hoehn, L. Pratt, K. F. Watterson, G. Wilkinson, J. Chem. Soc. (1961) 2738.

6 B. L. Booth, R. N. Haszeldine, P. R. Mitchell, J. J. Cox, Chem. Commun. (1967) 529.

7 B. L. Booth, R. N. Haszeldine, P. R. Mitchell, J. J. Cox, J. Chem. Soc. A (1969) 691.

8 R. P. Hughes, Adv. Organomet. Chem. 31 (1990) 183-267.

9 R. P. Hughes, J. Fluorine Chem. 131 (2010) 1059-1070.

10 G. Paprott, S. Lehmann, K. Seppelt, Chem. Ber. 121 (1988) 727-733.

11 R. E. Banks, T. Harrison, R. N. Haszeldine, A. B. P. Lever, T. F. Smith and J. B. Walton, Chem. Commun. (1965) 30-31.

12 P. B. Hitchcock and R. Mason, Chem. Commun. (1966) 503-505.

13 R. K. Kochhar and R. Pettit, J. Organometal. Chem. 6 (1966) 272-278.

14 T. S. Piper and G. Wilkinson, J. Inorg. Nucl. Chem. 6 (1956) 104-124.

15 O. S. Mills, Acta. Cryst. 11 (1958) 620-623.

16 A. Mitschler, B. Rees and M. S. Lehmann, J. Am. Chem. Soc. 100 (1978) 3390-3397.

17 R. F. Bryan and P. T. Greene, J. Am. Chem. Soc. (1970) 3064-3068.

18 J. M. Deng, Q. S. Li, Y. M. Xie and R. B. King, New. J. Chem. 37 (2013) 2902-2910.

19 J. M. Deng, Q. S. Li, Y. M. Xie and R. B. King, Inorg. Chim. Acta. 416 (2014) 157-163.

20 S. Gong, Q. Luo, Q. S. Li, Y. Xie, R. B. King and H. F. Schaefer, New J. Chem. 39 (2015) 3708-3718.

21 S. Gong, Y. Wu, Q. S. Li, Y. Xie and R. B. King, J. Fluorine Chem. 151 (2013) 12-19.

22 M. Brynda, L. Gagliardi, P. O. Widmark, P. P. Power and B. O. Roos, Angew. Chem. Int. Ed. 45 (2006) 3804-3807.

23 N. Sieffert and M.Bühl, J. Am. Chem. Soc. 132 (2010) 8056-8070.

24 P. Schyman, W. Lai, H. Chen, Y. Wang and S. Shaik, J. Am. Chem. Soc. 133 (2011) 7977-7984.

25 R. D. Adams, W. C. Pearl, Y. O. Wong, Q. Zhang, M. B. Hall and J. R. Walensky, J. Am. Chem. Soc. 133 (2011) 12994-12997.

26 R. Lonsdale, J. Olah, A. J. Mulholland and J. N. Harvey, J. Am. Chem. Soc. 133 (2011) 15464-15474. 
27 L. Crawford, D. J. Cole-Hamilton, E. Drent and M. Bühl, Chem. Eur. J. 20 (2014) 13923-13926.

28 H. Zhekova, M. Krykunov, J. Autschbach and T. Ziegler, J. Chem. Theory. Comput. 10 (2014) 3299-3307.

29 M. Bühl and H. Kabrede, J. Chem. Theory. Comput. 2 (2006) 1282-1290.

30 A. D. Becke, J. Chem. Phys. 98 (1993) 5648-5652.

31 C. Lee, W. Yang and R. G. Parr, Phys. Rev. B. 37 (1988) 785-789.

32 A. D. Becke, Phys. Rev. A. 38 (1988) 3098-3100.

33 J. P. Perdew, Phys. Rev. B. 33 (1986) 8822-8824.

34 T. H. Dunning, J. Chem. Phys. 53 (1970) 2823-2833.

35 S. Huzinaga, J. Chem. Phys. 42 (1965) 1293-1320.

36 A. J. H. Wachters, J. Chem. Phys. 52 (1970) 1033-1036.

37 D. M. Hood, R. M. Pitzer and H. F. Schaefer, J. Chem. Phys. 71 (1979) 705-712.

38 M. J. Frisch, G. W. Trucks, H. B. Schlegel, G. E. Scuseria, M. A. Robb, J. R. Cheeseman, J. A. Montgomery, Jr., T. Vreven, K. N. Kudin, J. C. Burant, J. M. Millam, S. S. Iyengar, J. Tomasi, V. Barone, B. Mennucci, M. Cossi, G. Scalmani, N. Rega, G. A. Petersson, H. Nakatsuji, M. Hada, M. Ehara, K. Toyota, R. Fukuda, J. Hasegawa, M. Ishida, T. Nakajima, Y. Honda, O. Kitao, H. Nakai, M. Klene, X. Li, J. E. Knox, H. P. Hratchian, J. B. Cross, V. Bakken, C. Adamo, J. Jaramillo, R. Gomperts, R. E. Stratmann, O. Yazyev, A. J. Austin, R. Cammi, C. Pomelli, J. W. Ochterski, P. Y. Ayala, K. Morokuma, G. A. Voth, P. Salvador, J. J. Dannenberg, V. G. Zakrzewski, S. Dapprich, A. D. Daniels, M. C. Strain, O. Farkas, D. K. Malick, A. D. Rabuck, K. Raghavachari, J. B. Foresman, J. V. Ortiz, Q. Cui, A. G. Baboul, S. Clifford, J. Cioslowski, B. B. Stefanov, G. Liu, A. Liashenko, P. Piskorz, I. Komaromi, R. L. Martin, D. J. Fox, T. Keith, M. A. Al-Laham, C.Y. Peng, A. Nanayakkara, M. Challacombe, P. M. W. Gill, B. Johnson, W. Chen, M. W. Wong, C. Gonzalez and J. A. Pople, Gaussian 03, Revision D. 01, Gaussian, Inc., Wallingford CT, 2004

39 M. J. Frisch, G. W. Trucks, H. B. Schlegel, G. E. Scuseria, M. A. Robb, J. R. Cheeseman, G. Scalmani, V. Barone, B. Mennucci, G. A. Petersson, H. Nakatsuji, M. Caricato, X. Li, H. P. Hratchian, A. F. Izmaylov, J. Bloino, G. Zheng, J. L. Sonnenberg, M. Hada, M. Ehara, K. Toyota, R. Fukuda, J. Hasegawa, M. Ishida, T. Nakajima, Y. Honda, O. Kitao, H. Nakai, T. Vreven, J. A. Montgomery, Jr., J. E. Peralta, F. Ogliaro, M. Bearpark, J. J. Heyd, E. Brothers, K. N. Kudin, V. N. Staroverov, R. Kobayashi, J. Normand, K. Raghavachari, A. Rendell, J. C. Burant, S. S. Iyengar, J. Tomasi, M. Cossi, N. Rega, J. 
M. Millam, M. Klene, J. E. Knox, J. B. Cross, V. Bakken, C. Adamo, J. Jaramillo, R. Gomperts, R. E. Stratmann, O. Yazyev, A. J. Austin, R. Cammi, C. Pomelli, J. W. Ochterski, R. L. Martin, K. Morokuma, V. G. Zakrzewski, G. A. Voth, P. Salvador, J. J. Dannenberg, S. Dapprich, A. D. Daniels, Ö. Farkas, J. B. Foresman, J. V. Ortiz, J. Cioslowski, and D. J. Fox, Gaussian 09, Revision D. 01, Gaussian, Inc., Wallingford CT, 2013.

40 B. N. Papas and H. F. Schaefer, J. Mol. Struct. 760 (2006) 175-181.

41 H. Jacobsen and T. Ziegler, J. Am. Chem. Soc. 118 (1996) 4631-4635.

42 J. M. L. Martin, C. W. Bauschlicher and A. Ricca, Comput. Phys. Commun. 133 (2001) 189-201.

43. R. Colton and C. J. Commons, Aust. J. Chem., 28 (1975) 1673-1680.

44. C. J. Commons and B. F. Hoskins, Aust. J. Chem., 28 (1975) 1663-1672.

45 Y. Xie, J. W. Jang, R. B. King and H. F. Schaefer, Inorg. Chem. 42 (2003) 5219-5230.

46 Z. Zhang, Q. S. Li, Y. Xie, R. B. King and H. F. Schaefer, J. Phys. Chem. A 114 (2010) 486-497.

47 Z. Zhang, Q. S. Li, Y. Xie, R. B. King and H. F. Schaefer, J. Phys. Chem. A 114 (2010) 4672-4679.

48 M. Martin, B. Rees and A. Mitschler, Acta. Cryst. B38 (1982) 6-15.

49 F. Weinhold, and C. R. Landis, Valency and Bonding: A Natural Bond Order DonorAcceptor Perspective, Cambridge University Press, Cambridge, England, U. K., 2005, pp. 32-36.

50 L. S. Sunderlin, D. Wang, and R. R. Squires, J. Am. Chem. Soc. 115 (1993) 1206012070 .

51 S. E. Kabir, F. Ahmeda, S. Ghosh, M. R. Hassan, M. S. Islam, A. Sharmin, D. A. Tocher, D. T. Haworth, S. V. Lindeman, T. A. Siddique, D. W. Bennett and K. I. Hardcastle, J. Organometal. Chem. 693 (2008) 2657-2665. 


\section{Graphical Abstract}

Energetic Preference of Dative The $\mathrm{C}_{5} \mathrm{~F}_{6} \mathrm{Mn}_{2}(\mathrm{CO})_{n}(n=10,9,8,7)$ systems Fluorine-Manganese Bonds Over were investigated using density functional Direct Manganese-Manganese theory. Structures containing dative $\mathrm{F} \rightarrow \mathrm{Mn}$

Bonds in Binuclear Hexafluorocyclopentadiene Manganese Carbonyls

Juanjuan Tan, Shida Gong, Jianming Deng, ${ }^{\text {a }}$ Qianshu Li, Qiong Luo,* Yaoming Xie, ${ }^{c}$ and R. Bruce King* bonds from one or both $\mathrm{CF}_{2}$ fluorine atoms to one or both manganese atoms are energetically preferred over structures containing formal $\mathrm{Mn}-\mathrm{Mn}$ bonds for $\mathrm{C}_{5} \mathrm{~F}_{6} \mathrm{Mn}_{2}(\mathrm{CO})_{n}(n=9,8$, 7).

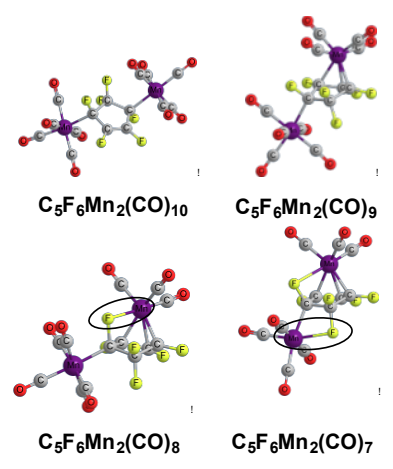

